\title{
Physiological and biochemical changes occurring in dwarf-cashew seedlings subjected to salt stress
}

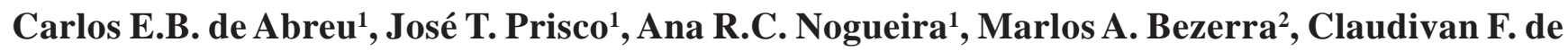 \\ Lacerda $^{3}$ and Enéas Gomes-Filho ${ }^{*}$
}

${ }^{1}$ Departamento de Bioquímica e Biologia Molecular, Universidade Federal do Ceará, CP 6039, 60455-900 Fortaleza, Ceará, Brazil. ㄹmbrapa Agroindústria Tropical, Rua Dra. Sara Mesquita, 2270 - Pici, 60511-110 Fortaleza, Ceará, Brazil. ${ }^{3}$ Departamento de Engenharia Agrícola, Universidade Federal do Ceará, 60455-900 Fortaleza, Ceará, Brazil. *Corresponding author: egomesf@ufc.br

Received: 05 March 2008; Returned for revision: 16 May 2008; Accepted: 11 June 2008

The effects of salt stress on some physiological and biochemical traits were evaluated in dwarf-cashew seedlings at the same developmental stage. Seeds were sown in trays containing vermiculite moistened with distilled water or with $\mathrm{NaCl}$ solutions having different electrical conductivities: 0.7, 1.8, 6.0, 9.8, 13.4, 17.4 and $20.6 \mathrm{dS} \mathrm{m}^{-1}$. Salinity delayed and inhibited seedling growth and development, particularly in the shoot. Concentrations of $\mathrm{Na}^{+}$and $\mathrm{Cl}^{-}$, but not of $\mathrm{K}^{+}$, increased with increasing stress severity. With the exception of proline, concentration of organic solutes was only marginally affected by salt stress. Catalase activity in leaves increased slightly as a result of salt stress, whereas guaiacol peroxidase activity was induced only under low levels of salt. In contrast, activities of guaiacol peroxidase and ascorbate peroxidase increased dramatically in roots. Apparently, roots were better protected against oxidative damage than shoots, as judged from the decrease in lipid peroxidation in root tissues. In leaves, expression of 75 proteins, evaluated by 2D electrophoresis, was altered by salt stress: 35 of them increased their expression and three were apparently de novo synthesized. In roots, 69 proteins were modified by salt stress: 34 proteins increased their expression and two proteins appeared only in stressed seedlings. The changes in protein patterns were caused by the imposed salt stress rather than by a response to the developmental stage. Overall, these responses could play an important role in salt stress acclimation of cashew seedlings.

Key words: Anacardium occidentale, antioxidant enzymes, lipid peroxidation, oxidative stress, protein pattern, salt stress

\begin{abstract}
Alterações fisiológicas e bioquímicas em plântulas de cajueiro anão-precoce submetidas ao estresse salino: $O$ objetivo deste trabalho foi avaliar os efeitos do estresse salino sobre algumas respostas fisiológicas e bioquímicas em plântulas de cajueiro anão-precoce no mesmo estádio de desenvolvimento. As sementes foram semeadas em bandejas contendo vermiculita umedecida com água destilada ou com soluções de $\mathrm{NaCl}$ de diferentes condutividades elétricas: 0,7, 1,8, 6,0, 9,8, 13,4, 17,4 e 20,6 dS m-1. A salinidade retardou e inibiu o crescimento e o desenvolvimento das plântulas, particularmente na parte aérea. As concentrações de $\mathrm{Na}^{+}$e $\mathrm{Cl}^{-}$, mas não as de $\mathrm{K}^{+}$, aumentaram em função do estresse salino. Exceto para prolina, as concentrações dos solutos orgânicos pouco variaram, em função do estresse salino. A atividade da catalase nas folhas aumentou levemente em função do estresse salino, enquanto a atividade da peroxidase do guaiacol foi induzida somente em baixos níveis de sal. Em contraste, as atividades das peroxidases do guaiacol e do ascorbato, nas raízes, aumentaram sobremodo. Os resultados sugerem uma proteção mais eficiente das raízes contra os danos oxidativos, resultando em um decréscimo na peroxidação dos lipídios. Observaram-se mudanças na expressão de 75 proteínas nas folhas, avaliadas por eletroforese 2D: 35 proteínas aumentaram sua expressão e três foram aparentemente sintetizadas de novo. Nas raízes, 69 proteínas foram modificadas pelo estresse salino: 34 proteínas
\end{abstract}


aumentaram sua expressão e duas foram encontradas somente nas plântulas estressadas. As mudanças nos padrões protéicos aconteceram mais em função do estresse salino do que em resposta ao estádio de desenvolvimento e podem desempenhar um papel importante na aclimatação das plântulas de cajueiro ao estresse salino.

Palavras-chave: Anacardium occidentale, enzimas antioxidativas, estresse oxidativo, estresse salino, padrões protéicos, peroxidação de lipídios

\section{INTRODUCTION}

The excess of soluble salts present in the irrigation water and in the soil solution is one of the major abiotic stresses that affect crop yield and the distribution of plant species in natural environments (Boyer, 1982). This problem reaches $20 \%$ of the irrigated areas of the world, occurring especially in the arid and semiarid regions, where about $25 \%$ of the irrigated land is affected by salts (FAO, 2005).

Inhibition of plant growth and development under salt conditions is, at least in part, due to both osmotic and ionic components, which may cause plant water deficit, unbalance of nutrients, and ion toxicity (Munns, 2002). The control of the rate of ion (mainly $\mathrm{Na}^{+}$and $\mathrm{Cl}^{-}$) uptake from the soil and its transport and distribution throughout the plant, as well as the capacity to compartmentalize ionic solutes in the vacuole at the same time that organic solutes accumulate in the cytoplasm (osmotic adjustment) have been considered as important mechanisms by which plants can tolerate salinity (Ashraf and Harris, 2004). The most common organic solutes (soluble carbohydrates, soluble amino-N, proline, etc.) accumulated by the plants are low molecular mass and hydrophilic compounds and since they do not interfere with cell metabolism, they are termed compatible solutes (Bohnert et al., 1995). The major function of these compatible solutes is related to the maintenance of water uptake, cell turgor and osmotic intracellular balance when ionic concentrations are lower in the citosol than in the vacuole, allowing cellular growth (Ashraf and Harris, 2004).

Generation of reactive oxygen species (ROS) in plant tissues, such as superoxide anion radicals $\left(\mathrm{O}_{2}{ }^{\bullet}-\right)$, hydroxyl radicals $\left({ }^{\bullet} \mathrm{OH}\right)$, singlet oxygen $\left({ }^{1} \mathrm{O}_{2}\right)$ and hydrogen peroxide $\left(\mathrm{H}_{2} \mathrm{O}_{2}\right)$, is a common response observed in saltstressed plants (Mittler, 2002; Vaidyanathan et al., 2003; Azevedo-Neto et al., 2006). So, in addition to its known osmotic and ionic effects, salt stress is also manifested as an oxidative stress (Hernández et al., 1995). These ROS are highly reactive and can alter the normal cellular metabolism through oxidative damage to proteins and nucleic acids, as well as causing peroxidation of membrane lipids (Møller et al., 2007). In order to prevent oxidative damages, plants have evolved a complex antioxidant system, which includes both enzymatic (scavenger enzymes) and non-enzymatic (mainly ascorbate and glutathione) components differentially found in cell compartments (Mittler, 2002). Enzymatic components include superoxide dismutase (SOD), which is a major scavenger of $\mathrm{O}_{2}{ }^{-}-$free radicals, converting them into $\mathrm{O}_{2}$ and $\mathrm{H}_{2} \mathrm{O}_{2}$. The $\mathrm{H}_{2} \mathrm{O}_{2}$ may be scavenged by a variety of peroxidases; including catalase (CAT), ascorbate peroxidase (APX) which uses ascorbate as electron donor in the first step of the ascorbate glutathione cycle, and guaiacol peroxidase (GPX), that decompose $\mathrm{H}_{2} \mathrm{O}_{2}$ by oxidation of co-substrates such as phenolic compounds and/or ascorbate. The capacity to scavenge ROS and to reduce their damaging effects on macromolecules appears to represent an important stress tolerance trait (Amor et al., 2005). A close correlation between the antioxidant capacity and $\mathrm{NaCl}$ tolerance has been demonstrated in several crops such as rice (Vaidyanathan et al., 2003), tomato (Mittova et al., 2002) and maize (Azevedo-Neto et al., 2006).

Another important feature of salt stress is related to changes in gene expression and protein pattern occurring along plant development. Salt-induced modifications in protein pattern are well-documented (Kav et al., 2004), but the breeding for stress tolerance using these tools have proved difficult because of the large number of stress-associated genes (Vinocur and Altman, 2005). Some genes expressed in response to salt stress are involved in the synthesis and accumulation of osmolytes, contributing to osmotic adjustment, while others may code for enzymes involved in detoxifying ROS or for the synthesis of antioxidants (Sairam and 
Tyagi, 2004). Therefore, the responses of plants to salinity and the development of salt tolerance are extremely complex events and various mechanisms appear to be involved. In addition, because salinity causes both an inhibition in growth and retardation in development, the use of seedlings having the same chronological age makes it extremely difficult to separate the changes due to salinity itself, from those caused by developmental process (Sousa et al., 2003). From the above, we investigated the effects of salt stress on growth and development of cashew (one of the major sources -cashew-nut and cashew-apple- of income for agriculture in the Brazilian semi-arid regions) seedlings at the same developmental stage, which were associated with changes in organic and inorganic solute accumulation, lipid peroxidation, antioxidative enzyme system, and protein patterns from both leaves and roots. This knowledge will contribute to improve our understanding on the cashew's acclimation process to salinity conditions, for which little information is yet available.

\section{MATERIAL AND METHODS}

Plant material and growth conditions: Selected dwarfcashew (Anacardium occidentale L.) seeds from clone CCP 06, obtained from Embrapa Agroindústria Tropical, Fortaleza, CE, Brazil, were sown in plastic trays containing vermiculite moistened $(2: 1, \mathrm{v} / \mathrm{v})$ with distilled water (control treatment) or with $\mathrm{NaCl}$ solutions having different electrical conductivity (EC): $0.7,1.8,6.0,9.8,13.4,17.4$ and $20.6 \mathrm{dS} \mathrm{m}^{-1}$ (saline treatment). The trays were placed into a growth room under a mean air temperature of $28.5 \pm 0.4^{\circ} \mathrm{C}$, air relative humidity of $81.7 \pm 3.5 \%$, and photoperiod of $12 \mathrm{~h}$. During the experimental period the photosynthetic active radiation on top of the seedlings was about $70 \mu \mathrm{mol} \mathrm{m} \mathrm{m}^{-2} \mathrm{~s}^{-1}$. The trays were weighted and irrigated daily with distilled water to replace the losses by evapotranspiration. The experiment was set up in a randomized design with four replicates, and each experimental unit was composed of six seedlings. Evaluations (growth parameters and biochemical assays) were performed when seedlings reached developmental stage 8 [DSt 8 - seedlings with axillary buds at the earliest formation, as defined by Cavalcanti Junior (1994)]. Leaf area was measured using a leaf area meter LI-3000 (LI-COR, Inc., Lincoln, NE, USA), and then the seedlings were separated into leaves, stem and roots, and immediately frozen in liquid nitrogen, lyophilized, weighed (dry mass), and kept at $-20^{\circ} \mathrm{C}$ for further analysis.

Organic and inorganic solutes determinations: Organic and inorganic solutes were extracted by homogenizing 100 mg of lyophilized leaf or root tissue in a mortar and pestle with $10 \mathrm{~mL}$ of deionized water. The homogenate was maintained under constant agitation during $30 \mathrm{~min}$ and centrifuged at $3,000 \mathrm{~g}$ for $15 \mathrm{~min}$. The supernatant was filtered through filter paper and kept at $-25^{\circ} \mathrm{C}$ until required.

Concentrations of $\mathrm{Na}^{+}$and $\mathrm{K}^{+}$were determined by flame photometry (Malavolta et al., 1989), whereas $\mathrm{Cl}^{-}$was determined espectrophometrically following the $\mathrm{Hg}(\mathrm{SCN})_{2}-$ $\mathrm{Fe}\left(\mathrm{NO}_{3}\right)_{3}$ method described by Gaines et al. (1984).

Soluble carbohydrate determination was based on the phenol-sulfuric acid method (Dubois et al., 1956). Soluble amino-N concentration was measured spectrophotometrically following the ninhydrin method described by Yemm and Cocking (1955). Proline was determined spectrophotometrically following the ninhydrin method described by Bates et al. (1973). Results (means $\pm \mathrm{SD}$ ) were expressed as $\mathrm{mmol} \mathrm{kg}^{-1}$ dry mass (DM).

Activities of antioxidative enzymes: Lyophilized leaf or root powder $(100 \mathrm{mg})$ were homogenized in a mortar and pestle with $5 \mathrm{~mL}$ of ice-cold extraction buffer ( $50 \mathrm{mM}$ TrisHCl buffer, $\mathrm{pH}$ 8.0, 0.1 mM EDTA), and the extraction was allowed to proceed for $2 \mathrm{~h}$. The homogenate was filtered through muslin cloth and centrifuged at 15,000 $g$ for 15 min. The supernatant fraction was used as crude extract for enzyme activity and lipid peroxidation assays. For ascorbate peroxidase extraction, $2 \mathrm{mM}$ ascorbate was added to the extraction buffer. All operations were carried out at $4^{\circ} \mathrm{C}$.

Total superoxide dismutase (SOD - EC 1.15.1.1) activity was determined by measuring its ability to inhibit the photochemical reduction of nitro blue tetrazolium chloride (NBT) as described by Giannopolitis and Ries (1977), with minor modifications. The reaction mixture contained $33.3 \mathrm{mM}$ phosphate buffer (pH 7.8), $66.6 \mu \mathrm{M}$ EDTA, $13 \mathrm{mM}$ methionine, $75 \mu \mathrm{M}$ NBT, $2 \mathrm{mM}$ riboflavin and $50 \mu \mathrm{L}$ of diluted enzyme extract in a final assay volume of 1.5 $\mathrm{mL}$. The photoreduction of NBT was assayed espectrophotometrically at $560 \mathrm{~nm}$ and it was inversely proportional to SOD activity. The reaction mixture with no 
enzyme developed maximum color due to maximum reduction of NBT. The blank solution had the same complete reaction mixture but it was kept in the dark. One unit of SOD activity (U) was defined as the amount of enzyme required to cause $50 \%$ inhibition of the NBT photoreduction rate. The results were expressed as $\mathrm{U} \mathrm{g}^{-1} \mathrm{DM}$.

Total catalase (CAT - EC 1.11.1.6) activity was measured according to Beers and Sizer (1952), with minor modifications. The reaction mixture consisted of $86 \mathrm{mM}$ phosphate buffer (pH 7.0), $86 \mu \mathrm{M}$ EDTA, $20 \mathrm{mM} \mathrm{H}_{2} \mathrm{O}_{2}$ and $150 \mu \mathrm{L}$ enzyme extract in a final assay volume of $1.5 \mathrm{~mL}$. The rate of disappearance of $\mathrm{H}_{2} \mathrm{O}_{2}$ was monitored at 240 $\mathrm{nm}$ during $10 \mathrm{~min}$ [molar extinction coefficient $(\varepsilon), 36 \mathrm{M}^{-1}$ $\left.\mathrm{cm}^{-1}\right]$. Results were expressed as $\mu \mathrm{mol} \mathrm{H}_{2} \mathrm{O}_{2} \min ^{-1} \mathrm{~g}^{-1} \mathrm{DM}$.

Total guaiacol peroxidase (GPX - EC 1.11.1.7) activity was determined as described by Urbanek et al. (1991), with minor modifications. The reaction mixture contained $47.5 \mathrm{mM}$ phosphate buffer (pH 7.0), $47.5 \mu \mathrm{M}$ EDTA, 5.0 $\mathrm{mM}$ guaiacol, $15.0 \mathrm{mM} \mathrm{H}_{2} \mathrm{O}_{2}$ and $50 \mu \mathrm{L}$ enzyme extract in a final assay volume of $2 \mathrm{~mL}$. The tetraguaiacol formation was monitored at $470 \mathrm{~nm}$ for $1 \mathrm{~min}\left(\varepsilon, 26.6 \mathrm{mM}^{-1} \mathrm{~cm}^{-1}\right)$. The results were expressed as $\mu \mathrm{mol} \mathrm{H}_{2} \mathrm{O}_{2} \min ^{-1} \mathrm{~g}^{-1} \mathrm{DM}$ taking into consideration that $4 \mathrm{~mol}_{2} \mathrm{O}_{2}$ are reduced to produce 1 mol of tetraguaiacol (Azevedo-Neto et al., 2006).

Total ascorbate peroxidase (APX - EC 1.11.1.1) activity was determined as described by Nakano and Asada (1981), with minor modifications. The reaction mixture contained $36.6 \mathrm{mM}$ phosphate buffer ( $\mathrm{pH}$ 6.0), $36.6 \mu \mathrm{M}$ EDTA, $1.0 \mathrm{mM} \mathrm{H}_{2} \mathrm{O}_{2}, 0.5 \mathrm{mM}$ ascorbate and 300 $\mu \mathrm{L}$ enzyme extract in a final assay volume of $1.5 \mathrm{~mL}$. The ascorbate oxidation was monitored at $290 \mathrm{~nm}$ during $5 \mathrm{~min}$ $\left(\varepsilon, 2.8 \mathrm{mM}^{-1} \mathrm{~cm}^{-1}\right)$. The results were expressed as $\mu \mathrm{mol}$ $\mathrm{H}_{2} \mathrm{O}_{2} \mathrm{~min}^{-1} \mathrm{~g}^{-1} \mathrm{DM}$ taking into consideration that $1 \mathrm{~mol}$ of ascorbate is required for the reduction of $1 \mathrm{~mol}$ of $\mathrm{H}_{2} \mathrm{O}_{2}$ (Azevedo-Neto et al., 2006).

For all enzymatic assays, the mixtures were maintained at $30^{\circ} \mathrm{C}$ and each extract was run in duplicate. The results were compared by the means $\pm \mathrm{SD}$.

Lipid peroxidation: Lipid peroxidation was determined by measuring the amount of malondialdehyde (MDA) produced by the thiobarbituric acid reaction as described by Heath and Packer (1968). The enzyme extract was mixed with the same volume of a $0.5 \%(\mathrm{w} / \mathrm{v})$ thiobarbituric acid solution containing $20 \%$ (w/v) tricholoracetic acid
(TCA). The mixture was heated at $95^{\circ} \mathrm{C}$ for $30 \mathrm{~min}$ and then quickly cooled in an ice-bath. The mixture was centrifuged at 3,000 $\mathrm{g}$ for $10 \mathrm{~min}$ and the absorbance (Abs) of the supernatant measured at 532 and $600 \mathrm{~nm}$. The MDA concentration was determined by $\left(A b s_{532}-A b s_{600}\right)$ and $(\varepsilon$, $\left.155 \mathrm{mM}^{-1} \mathrm{~cm}^{-1}\right)$ ratio, and the result expressed as $\mu \mathrm{mol}$ MDA kg-1 DM.

Protein extraction and 2-D electrophoresis: Protein patterns were obtained for both control and stressed (EC $17.4 \mathrm{dS} \mathrm{m}^{-1}$ ) seedlings. Proteins were extracted by taking $200 \mathrm{mg}$ of lyophilized leaf or root powder and $200 \mathrm{mg}$ of PVPP, and suspending them in $5 \mathrm{~mL}$ of extraction buffer, containing $40 \mathrm{mM}$ Tris-HCl, $\mathrm{pH}$ 7.5, $250 \mathrm{mM}$ sucrose, 10 mM EDTA, 1\% Triton X-100, 1.0 mM PMSF and $1.0 \mathrm{mM}$ DTT. The suspension was shaken for $60 \mathrm{~min}$ and centrifuged at $15,000 \mathrm{~g}$ at $4^{\circ} \mathrm{C}$ for $15 \mathrm{~min}$. The proteins from the supernatant were precipitated with $10 \%$ TCA in cold acetone and kept overnight at $-20^{\circ} \mathrm{C}$. The mixture was centrifuged at $15,000 \mathrm{~g}$ at $4^{\circ} \mathrm{C}$ for $15 \mathrm{~min}$ and the precipitate washed four times with cold acetone. The precipitated proteins were resuspended in $300 \mu \mathrm{L}$ lysis buffer contained $7 \mathrm{M}$ urea, $2 \mathrm{M}$ thiourea, 2\% CHAPS, 2\% IPG buffer pH 3-10 (Amersham Bioscience, Sweden) and $0.3 \%$ DTT. The first protein separation was carried by isoeletric focusing (IEF) at $20^{\circ} \mathrm{C}$ on a Multiphor II system (Pharmacia Biotech, France) using Immobiline DryStrip (13 cm), pH 4-7 (Amersham Biosciences, Sweden). The strips were rehydrated overnight with sample containing $50 \mu \mathrm{g}$ of proteins in $8 \mathrm{M}$ urea, 2\% CHAPS, 2\% IPG buffer $\mathrm{pH} 3-10,0.3 \%$ DTT and traces of bromophenol blue. It took 5 min to reach the starting voltage $(300 \mathrm{~V})$, then it was increased slowly for $90 \mathrm{~min}$ to reach $3500 \mathrm{~V}$, and finally it was kept at $3500 \mathrm{~V}$ for $250 \mathrm{~min}$. After IEF, the strips were first equilibrated with $1 \%$ DTT in a buffer containing $50 \mathrm{mM}$ Tris-HCl, pH 8.8, $6 \mathrm{M}$ urea, 30\% glycerol, 2\% SDS and traces of bromophenol blue for 15 min, and then with $2.5 \%$ iodoacetamide in the same buffer for more $15 \mathrm{~min}$. The strips were briefly washed with running buffer and placed on top of a $12.5 \%$ polyacrylamide gel (160 x $180 \times 1.5 \mathrm{~mm})$ and the second dimension for protein separation was performed in a vertical electrophoresis system (Laemmli, 1970). Afterwards, the proteins in the gel were stained with silver (Blum et al., 1987), and protein patterns were 
digitized using a calibrated ImageScanner model UTA1100 (Amersham Biosciences).

Protein concentration was determined according to Bradford (1976), using BSA as standard.

Analysis of protein patterns: Three gels were prepared for each condition, one of them being selected as reference gel. The intensity of protein spots on the gels was measured by an Imagemaster 2D Platinum software version 6.0 (Amersham Biosciences) and variations in protein expression were deemed valid if they were higher than 2 -fold. The isoelectric point $(\mathrm{p} I)$ and relative molecular mass $\left(\mathrm{M}_{\mathrm{r}}\right)$ of each protein were determined using marker proteins (Dalton Mark VII-L, Sigma Chemical Company), applied together with the sample.

\section{RESULTS}

Plant growth: Seedlings subjected to saline solutions with EC 0 to $6.0 \mathrm{dS} \mathrm{m}^{-1}$ reached DSt 8 on the 21st day after sowing (Figure 1), while it took 25, 27, 31 and $40 \mathrm{~d}$ to reach the same DSt when exposed to solutions with EC 9.8, 13.4, 17.4 and $20.6 \mathrm{dS} \mathrm{m}^{-1}$, respectively (data not shown). Also, the emergence of seedlings grown under high salinity (20.6 dS $\mathrm{m}^{-1}$ ) was completely suppressed, and for this reason it was excluded from Figure 1. Salt stress reduced leaf area (LA) and shoot dry mass (SDM), but its effect on root dry mass (RDM) was not so conspicuous (Figure 2). The SDM/RDM ratio was not affected at $\mathrm{EC} \leq 9.8 \mathrm{dS} \mathrm{m} \mathrm{m}^{-1}$, however at $13.4 \mathrm{dS}$ $\mathrm{m}^{-1}$ this ratio suffered a reduction of $25.9 \%$ in relation to the control and remained stable up to the highest EC tested.

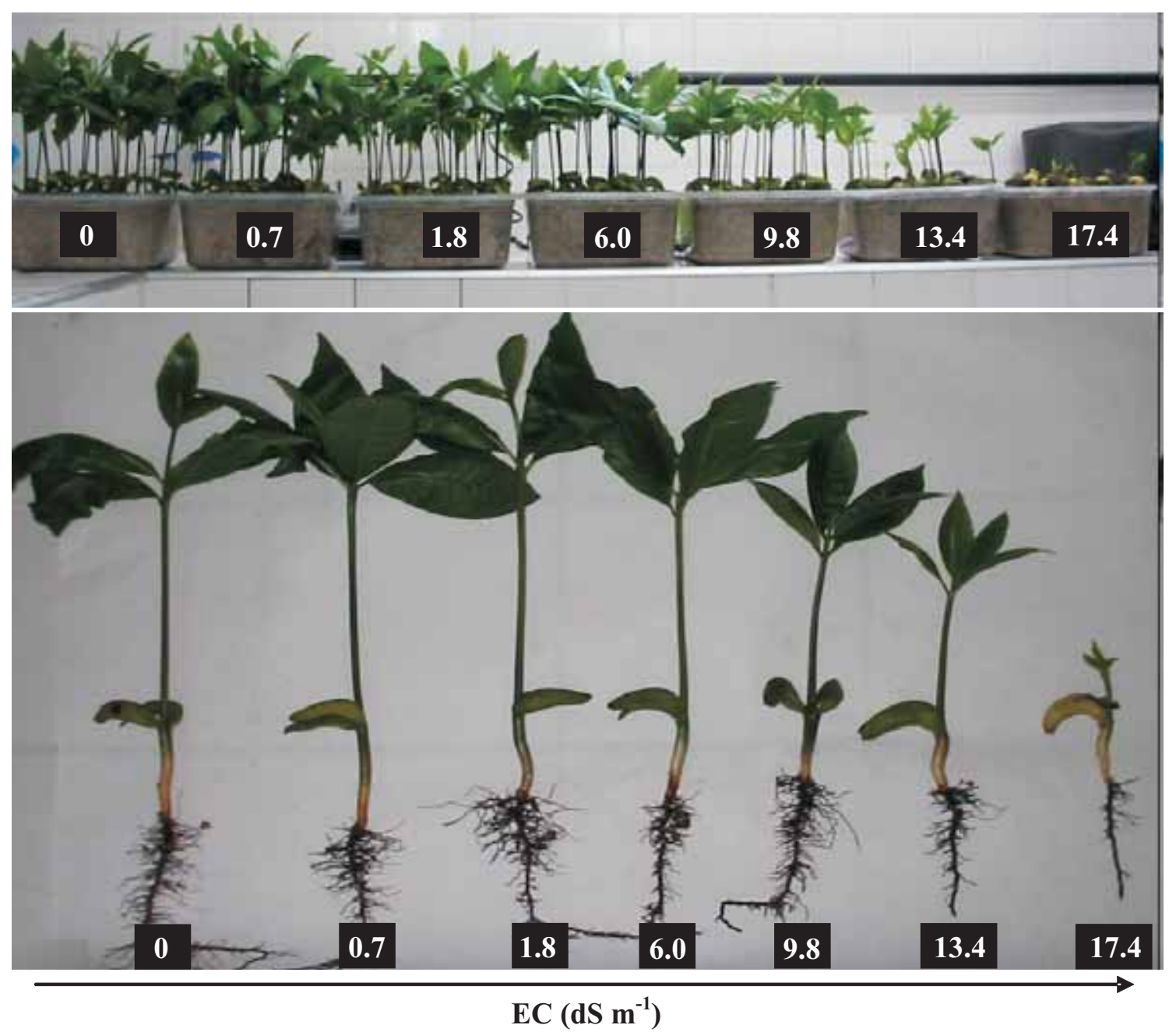

Figure 1. Dwarf-cashew seedlings of clone CCP 06 on the $21^{\text {st }}$ day after sowing. Seedlings were subjected to control ( 0 $\left.\mathrm{dS} \mathrm{m} \mathrm{m}^{-1}\right)$ and salt stress $\left(0.7,1.8,6.0,9.8,13.4\right.$ and $\left.17.4 \mathrm{dS} \mathrm{m}^{-1}\right)$ conditions. 


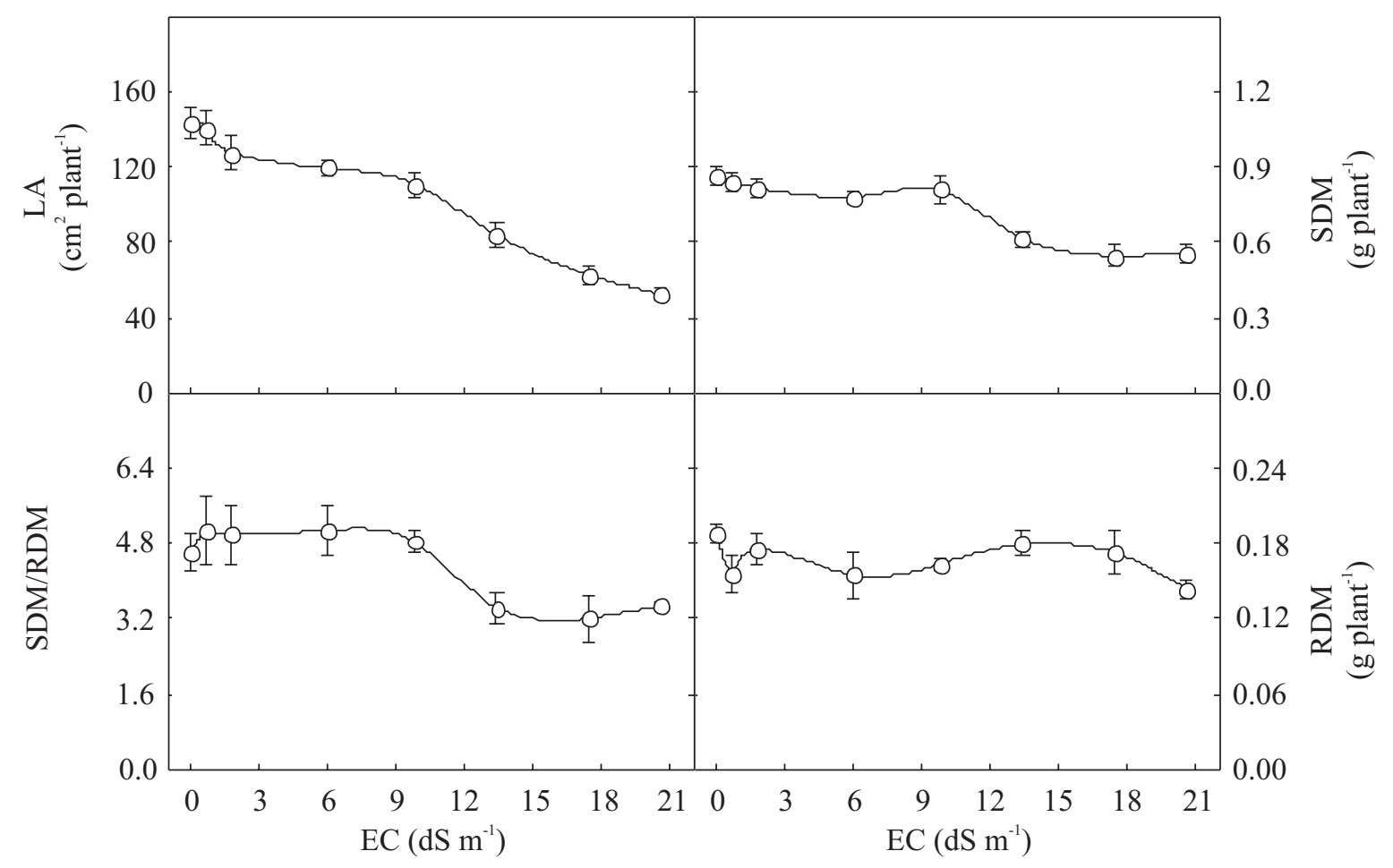

Figure 2. Leaf area (LA), shoot (SDM) and root (RDM) dry masses, and SDM/RDM ratio from dwarf-cashew seedlings of clone CCP 06, grown under control $\left(0 \mathrm{dS} \mathrm{m} \mathrm{m}^{-1}\right)$ and salt stress $\left(0.7,1.8,6.0,9.8,13.4,17.4\right.$ and $\left.20.6 \mathrm{dS} \mathrm{m}^{-1}\right)$ conditions. $n$ $=4 \pm \mathrm{SD}$.

Organic and inorganic solute concentrations: Leaf and root soluble carbohydrates and root soluble amino- $\mathrm{N}$ concentrations were not affected by salinity (Figure 3). However, the concentration of leaf soluble amino- $\mathrm{N}$ increased slightly with salt stress. Leaf proline concentration increased slightly with salinity up to EC 6.0

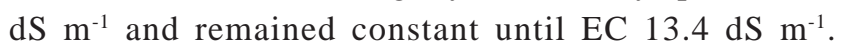
Afterwards, the increase in proline concentration was greater and at the highest EC it reached values 186\% greater than the control. Root proline concentration increased with salt stress and at EC $20.6 \mathrm{dS} \mathrm{m}^{-1}$ it was twice that of the control.

Ions $\mathrm{Na}^{+}$and $\mathrm{Cl}^{-}$accumulated in both leaves and roots due to salt stress (Figure 4). Leaf $\mathrm{Na}^{+}$and $\mathrm{Cl}^{-}$ concentrations increased slowly up to EC $9.8 \mathrm{dS} \mathrm{m}^{-1}$ and then remained constant. Root $\mathrm{Na}^{+}$and $\mathrm{Cl}^{-}$concentrations increased rapidly with salt up to the EC 6.0-9.8 $\mathrm{dS} \mathrm{m}^{-1}$ $\left(\mathrm{Na}^{+}\right)$or $6.0 \mathrm{dS} \mathrm{m}{ }^{-1}\left(\mathrm{Cl}^{-}\right)$, and then started to decrease, and increased again at EC $20.6 \mathrm{dS} \mathrm{m} \mathrm{m}^{-1}$. When $\mathrm{Na}^{+}$and $\mathrm{Cl}^{-}$ concentrations in leaves and roots of stressed seedlings were compared, roots accumulated $139 \%$ more $\mathrm{Na}^{+}$and $182 \%$ more $\mathrm{Cl}^{-}$than the leaves at the highest EC studied.
Since salt stress did not affect $\mathrm{K}^{+}$concentrations especially in leaves, it can be inferred that the salt-induced variations in $\mathrm{Na}^{+} / \mathrm{K}^{+}$ratios mainly resulted from changes in $\mathrm{Na}^{+}$levels. Leaf $\mathrm{Na}^{+} / \mathrm{K}^{+}$ratio increased slightly up to EC $6.0 \mathrm{dS} \mathrm{m}^{-1}$ and was maintained until EC $20.6 \mathrm{dS} \mathrm{m}{ }^{-1}$. Root $\mathrm{Na}^{+} / \mathrm{K}^{+}$ratio showed the same behavior as $\mathrm{Na}^{+}$, increasing rapidly up to EC 9.8 dS m-1, and then decreasing until EC 13.4-17.4 dS m and finally, increasing again at the highest salinity tested.

Antioxidative enzymes: Leaf SOD activity increased at EC $0.7 \mathrm{dS} \mathrm{m}^{-1}$ and remained constant (Figure 5). In control plants, SOD activity was about 1.5 -fold higher in roots than in leaves, but salt treatment did not affect SOD activity. Leaf CAT activity slightly increased in salt-stressed seedlings, reaching a value $75 \%$ higher than the control at EC $20.6 \mathrm{dS}^{-}$ ${ }^{1}$ (Figure 5). Root CAT activity was on average twice that of the leaves and it was not affected by salt stress, except at EC $20.6 \mathrm{dS} \mathrm{m}^{-1}$, when it was $21.9 \%$ lower than in control plants.

Leaf GPX activity of salt-stressed seedlings reached its maximum at EC $1.8 \mathrm{dS} \mathrm{m}^{-1}$ (ca. 98\% higher than control), when it started to decrease reaching at EC $17.4 \mathrm{dS} \mathrm{m}^{-1}$, the same value as the control, and then increased again at $20.6 \mathrm{dS}$ 


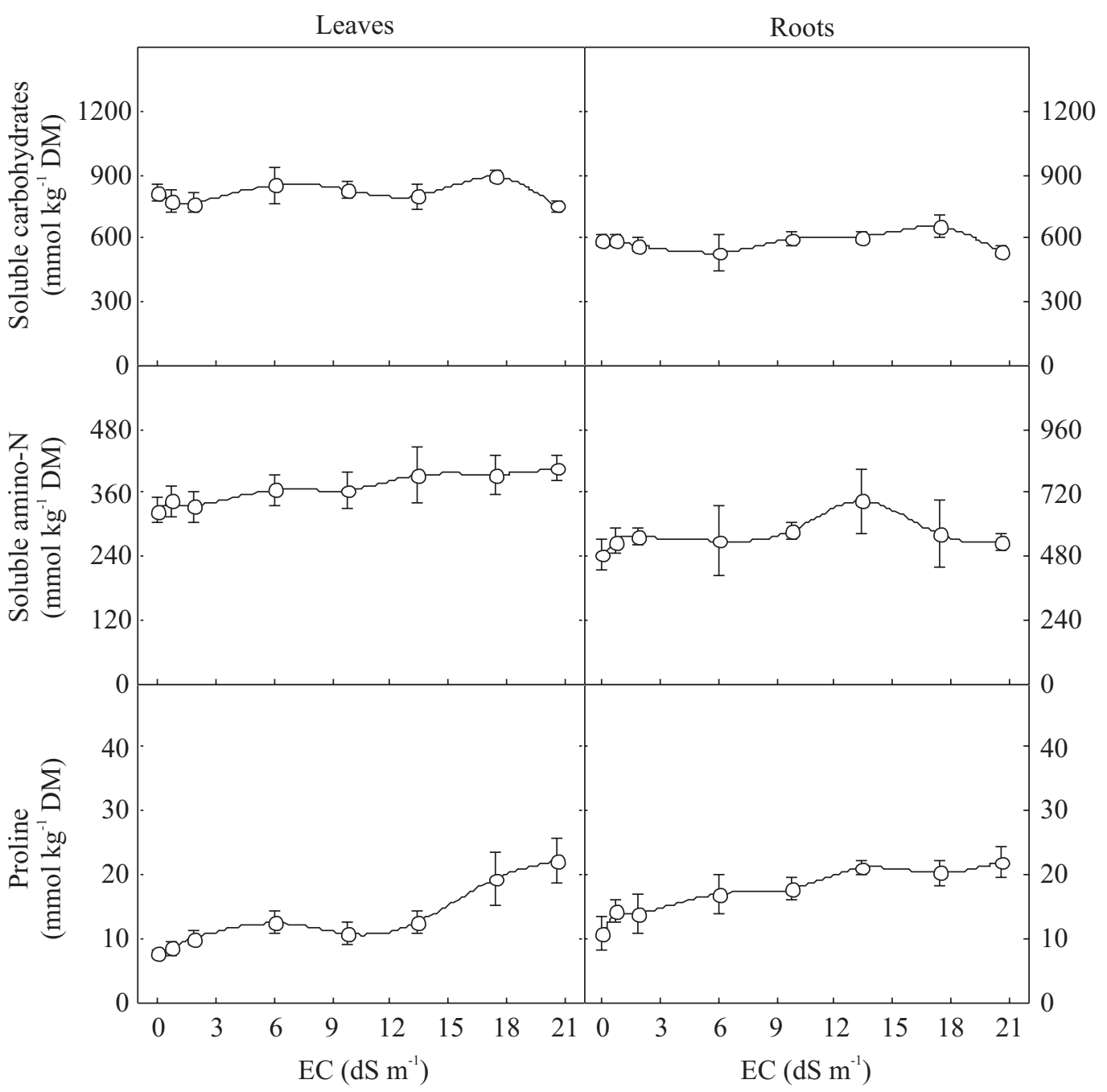

Figure 3. Soluble carbohydrates, soluble amino- $\mathrm{N}$ and proline concentrations in leaves and roots from dwarf-cashew seedlings of clone CCP 06 , grown under control $\left(0 \mathrm{dS} \mathrm{m}^{-1}\right)$ and salt stress $\left(0.7,1.8,6.0,9.8,13.4,17.4\right.$ and $\left.20.6 \mathrm{dS} \mathrm{m}^{-1}\right)$ conditions. $n=4 \pm$ SD.

$\mathrm{m}^{-1}$ (Figure 6). Root GPX activity showed a constant increase up to EC $13.4 \mathrm{dS} \mathrm{m}^{-1}$ when it reached its maximum activity (ca. 417\% higher than the control) and then decreased at EC $20.6 \mathrm{dS} \mathrm{m}^{-1}$. Although leaf APX activity was not affected by salt stress, root APX activity increased up to EC $13.4 \mathrm{dS} \mathrm{m}^{-1}$ and then remained constant (Figure 6).

Lipid peroxidation: There was a great increase in leaf lipid peroxidation (Figure 7), expressed as MDA, from EC 0 to $9.8 \mathrm{dS} \mathrm{m}^{-1}$, whereafter it continued to increase at a lower rate, to reach at EC $20.6 \mathrm{dS} \mathrm{m}^{-1}$ a value $135 \%$ higher than the control. In contrast, root peroxidation decreased with increasing stress intensity, reaching a value 53.7\% lower than the control at EC $20.6 \mathrm{dS} \mathrm{m} \mathrm{m}^{-1}$.
Protein expression profiles: Approximately 500 distinct proteins in leaves with relative molecular masses varying from 12.2 to $92.0 \mathrm{kDa}$ were detected (Figure 8). Seventyfive proteins changed their intensity by more than 2-fold under salt stress; of these, 35 proteins were induced by salinity stress. In addition, three proteins (18.8, 19.4 and $24.0 \mathrm{kDa}$ ) appeared to be de novo synthesized as a result of salt stress. In roots, about 300 proteins with relative molecular masses varying from 11.0 to $82.0 \mathrm{kDa}$ were found (Figure 9). The rate of synthesis of 69 proteins was modified by salt stress with 34 proteins being more expressed in the stressed seedlings. In addition, two proteins (50.8 and $17.3 \mathrm{kDa}$ ) were present only in stressed seedlings. 


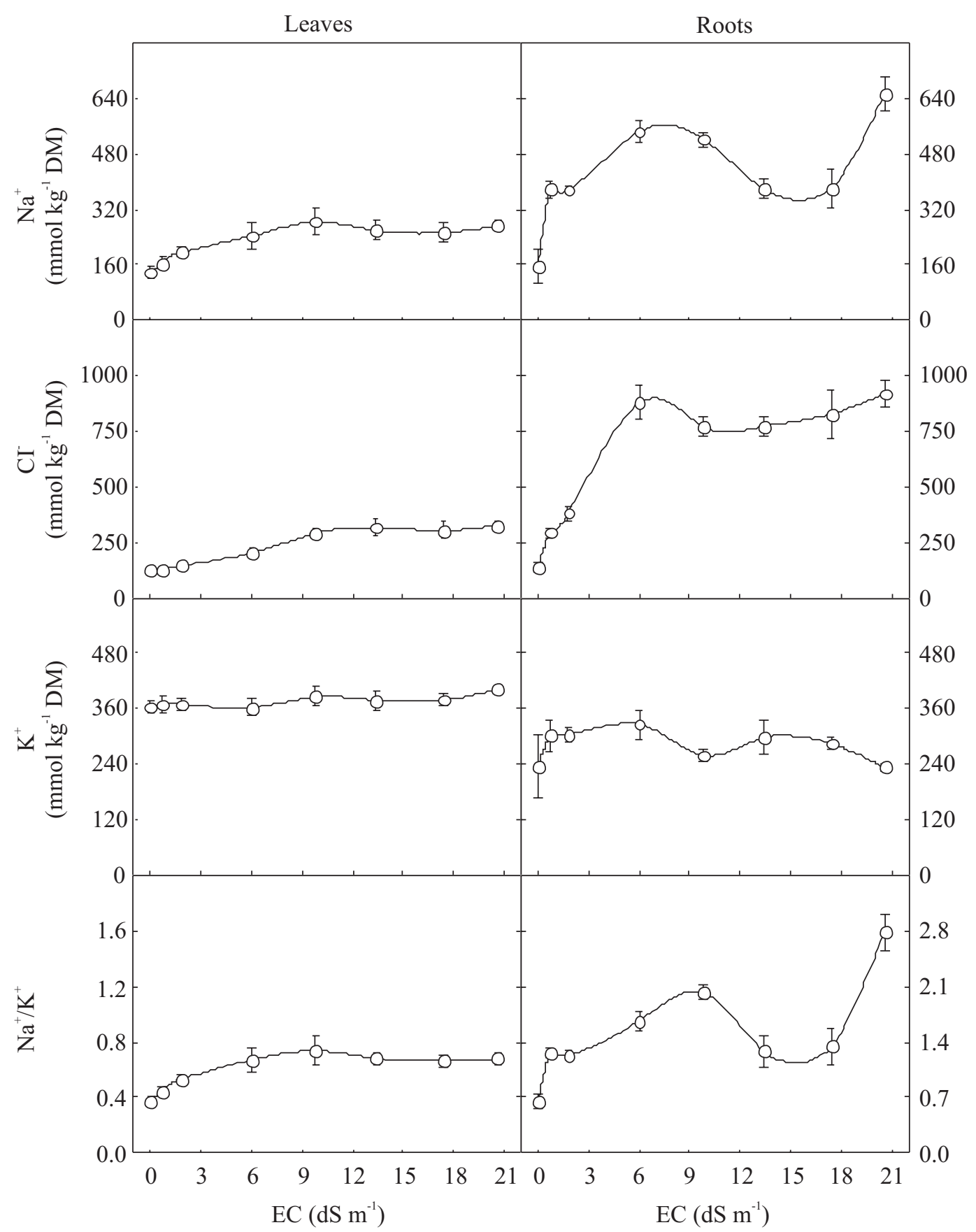

Figure 4. $\mathrm{Na}^{+}, \mathrm{Cl}^{-}, \mathrm{K}^{+}$concentrations and $\mathrm{Na}^{+} / \mathrm{K}^{+}$ratios in leaves and roots from dwarf-cashew seedlings of clone CCP 06 , grown under control $\left(0 \mathrm{dS} \mathrm{m}^{-1}\right)$ and salt stress $\left(0.7,1.8,6.0,9.8,13.4,17.4\right.$ and $\left.20.6 \mathrm{dS} \mathrm{m}^{-1}\right)$ conditions. $n=4 \pm$ SD.

\section{DISCUSSION}

Since the protein pattern varied with plant development and salt stress delayed seedling development it is difficult to separate the effects directly related to salt stress from those simply related to the variant protein pattern associated with distinct development stages (Sousa et al., 2003). Therefore, we evaluated seedlings with similar morpho-physiological, rather than chronological, age, in an attempt of avoiding the ontogenetic drift effects which easily hamper a useful interpretation of plant responses to salt stress. 


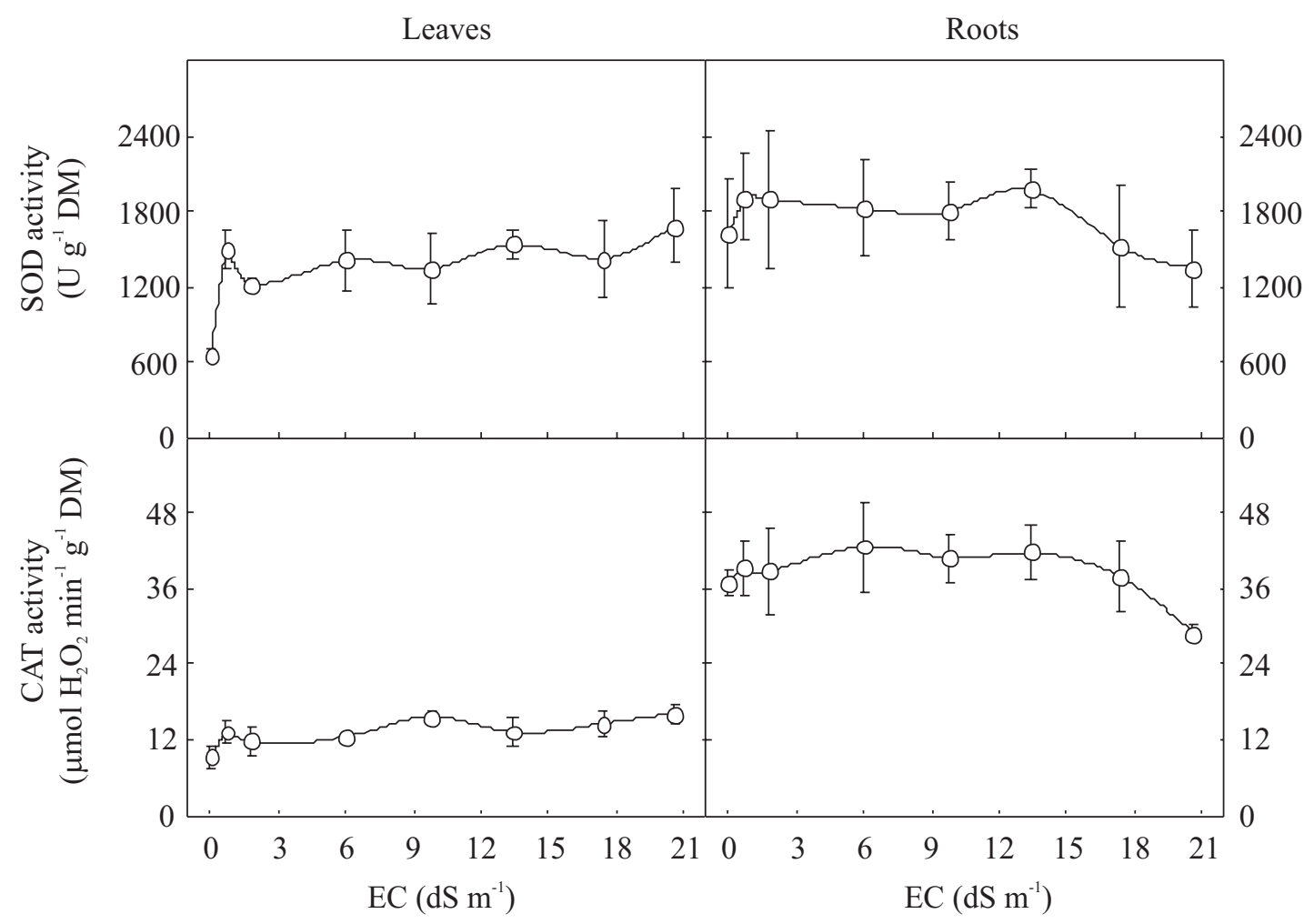

Figure 5. Total superoxide dismutase (SOD) and catalase (CAT) activities in leaves and roots from dwarf-cashew seedlings of clone CCP 06, grown under control $\left(0 \mathrm{dS} \mathrm{m}^{-1}\right)$ and salt stress $\left(0.7,1.8,6.0,9.8,13.4,17.4\right.$ and $\left.20.6 \mathrm{dS} \mathrm{m}^{-1}\right)$ conditions. $n=4 \pm$ SD.

The salt-induced inhibition of seedling growth, as evidenced herein by the reductions in dry mass production and leaf area, is also well-documented for different species (Costa et al., 2003; Lacerda et al., 2003a; Azevedo-Neto et al., 2004), including other woody plant species such as Eucalyptus camaldulensis and Dalbergia sissoo (Rawat and Banerjee, 1998). The suppression of plant growth under saline conditions may either be due to osmotic reduction in water availability or to excessive ion $\left(\mathrm{Na}^{+}\right.$and $\left.\mathrm{Cl}^{-}\right)$accumulation in plant tissues which may affect physiological processes such as the $\mathrm{CO}_{2}$ assimilation rate (Navarro et al., 2007). The decline in leaf area is thought to be an initial response of glycophytes to salinity that would avoid the excessive loss of water for transpiration; however, such reductions would result in less leaf area available for photosynthesis that would be responsible for a lower growth rate under salt stress conditions (Parida et al., 2004). In the present study, the greater salt-induced reduction of shoot growth compared to root growth might suggest a greater capacity of the roots to adjust osmotically, as well as a better protection against oxidative stress (see below), under salt stress conditions.

One of the most common stress responses in plants is overproduction of different types of compatible organic solutes (Ashraf and Harris, 2004). In our study, proline, rather than soluble carbohydrates and soluble amino- $\mathrm{N}$, remarkably accumulated in leaves and roots, especially in leaves at higher salt additions. Nevertheless, proline concentration was much lower than that of carbohydrate and soluble amino- $\mathrm{N}$ and apparently it was not sufficient to provide osmotic adjustment. Moreover, despite the fact that many investigators have associated salt tolerance with proline accumulation, this relationship is a contentious matter (Ashraf and Foolad, 2007). In some studies, proline accumulation was deemed to be a symptom of salt injury rather than an indication of salt tolerance (Lacerda et al., 2003b).

The preferential accumulation of $\mathrm{Na}^{+}$and $\mathrm{Cl}^{-}$in roots suggests the existence of a mechanism of ion retention in 


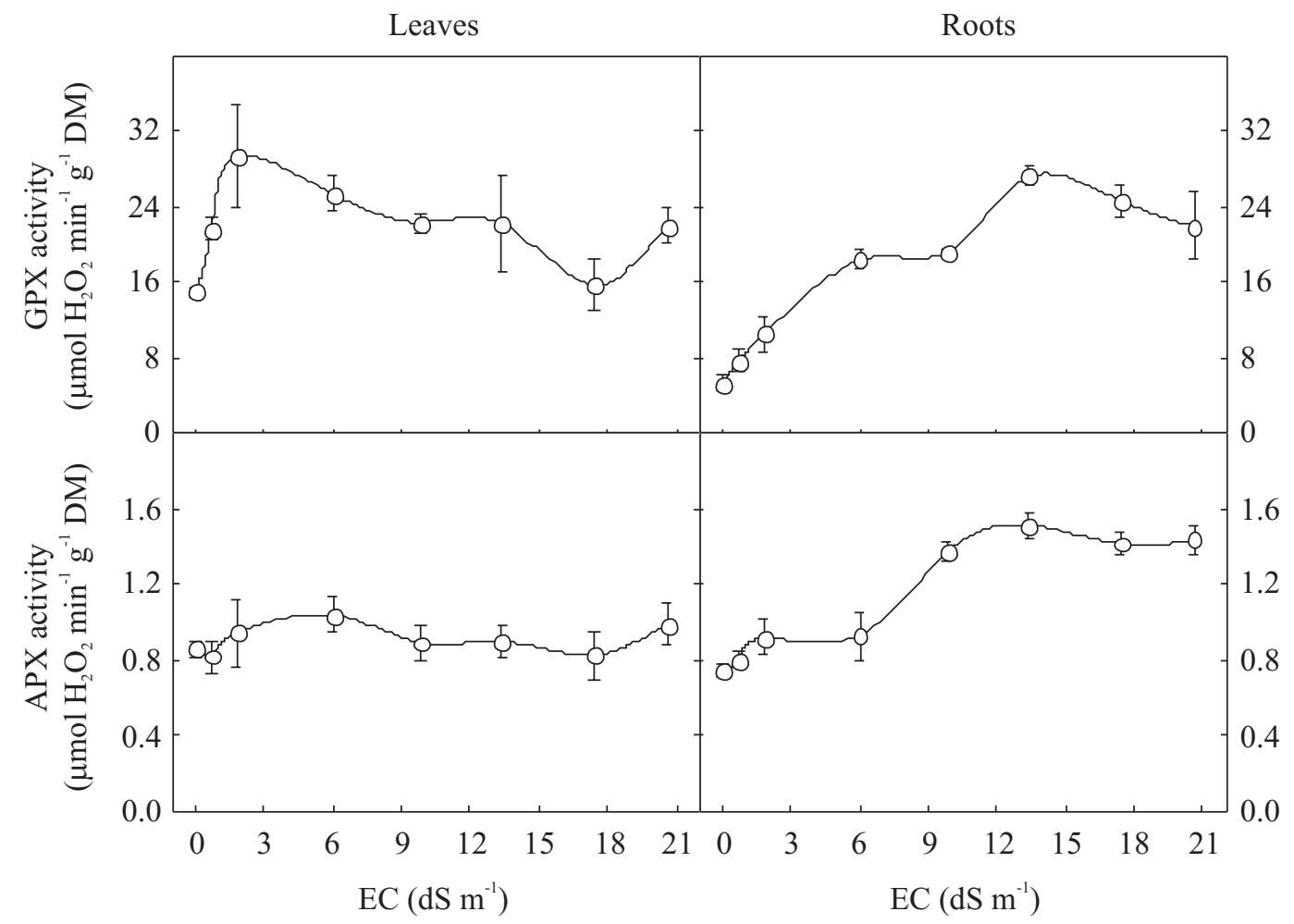

Figure 6. Total guaiacol peroxidase (GPX) and ascorbate peroxidase (APX) activities in leaves and roots from dwarfcashew seedlings of clone CCP 06, grown under control $\left(0 \mathrm{dS} \mathrm{m}^{-1}\right)$ and salt stress $(0.7,1.8,6.0,9.8,13.4,17.4$ and $20.6 \mathrm{dS}$ $\left.\mathrm{m}^{-1}\right)$ conditions. $n=4 \pm \mathrm{SD}$.

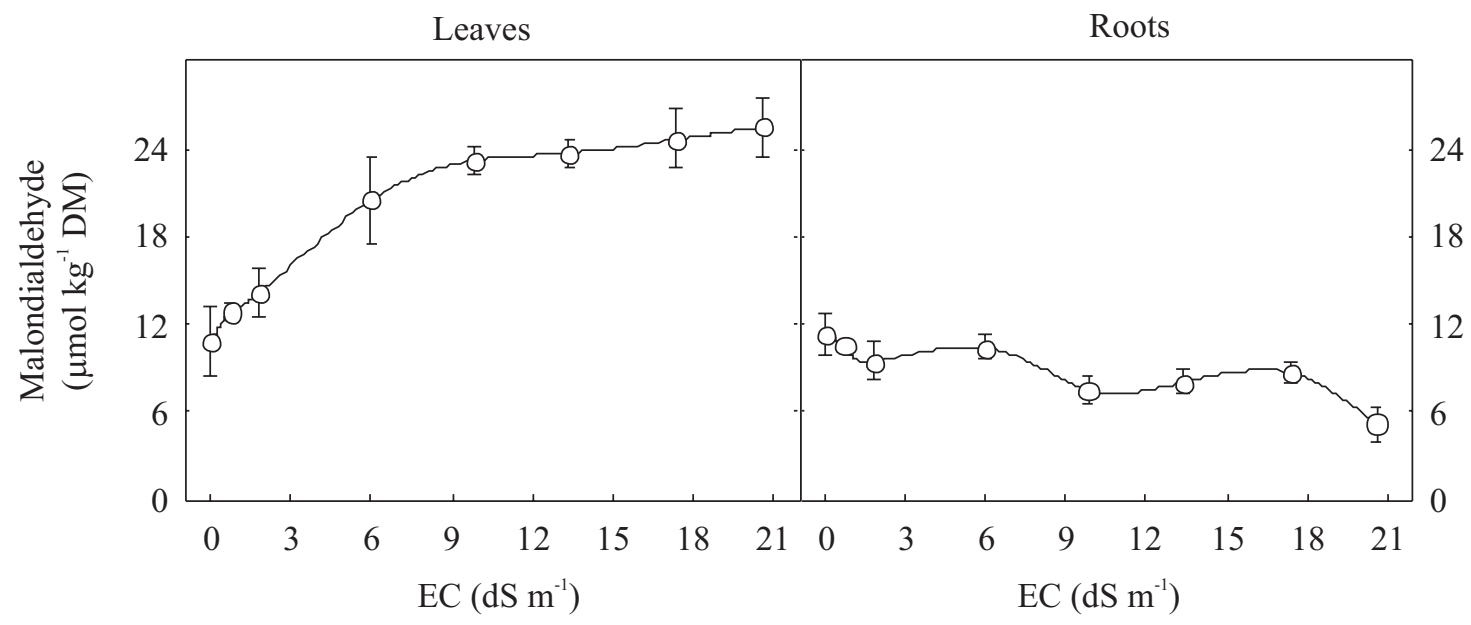

Figure 7. Malondialdehyde (MDA) concentration in leaves and roots from dwarf-cashew seedlings of clone CCP 06, grown under control $\left(0 \mathrm{dS} \mathrm{m}^{-1}\right)$ and salt stress $\left(0.7,1.8,6.0,9.8,13.4,17.4\right.$ and $\left.20.6 \mathrm{dS} \mathrm{m}^{-1}\right)$ conditions. $n=4 \pm \mathrm{SD}$.

this organ, which prevents the transport of toxic ions to the shoot without affecting root growth and contributes for its osmotic adjustment. This constitutes a mechanism of salt tolerance (Munns, 2002) allowing the plants to grow for extended periods, at least under low to moderate salinities. Despite these considerations, the relatively small salt accumulation in the shoot was sufficient to inhibit its growth. This inhibition could be attributed to the inability to 

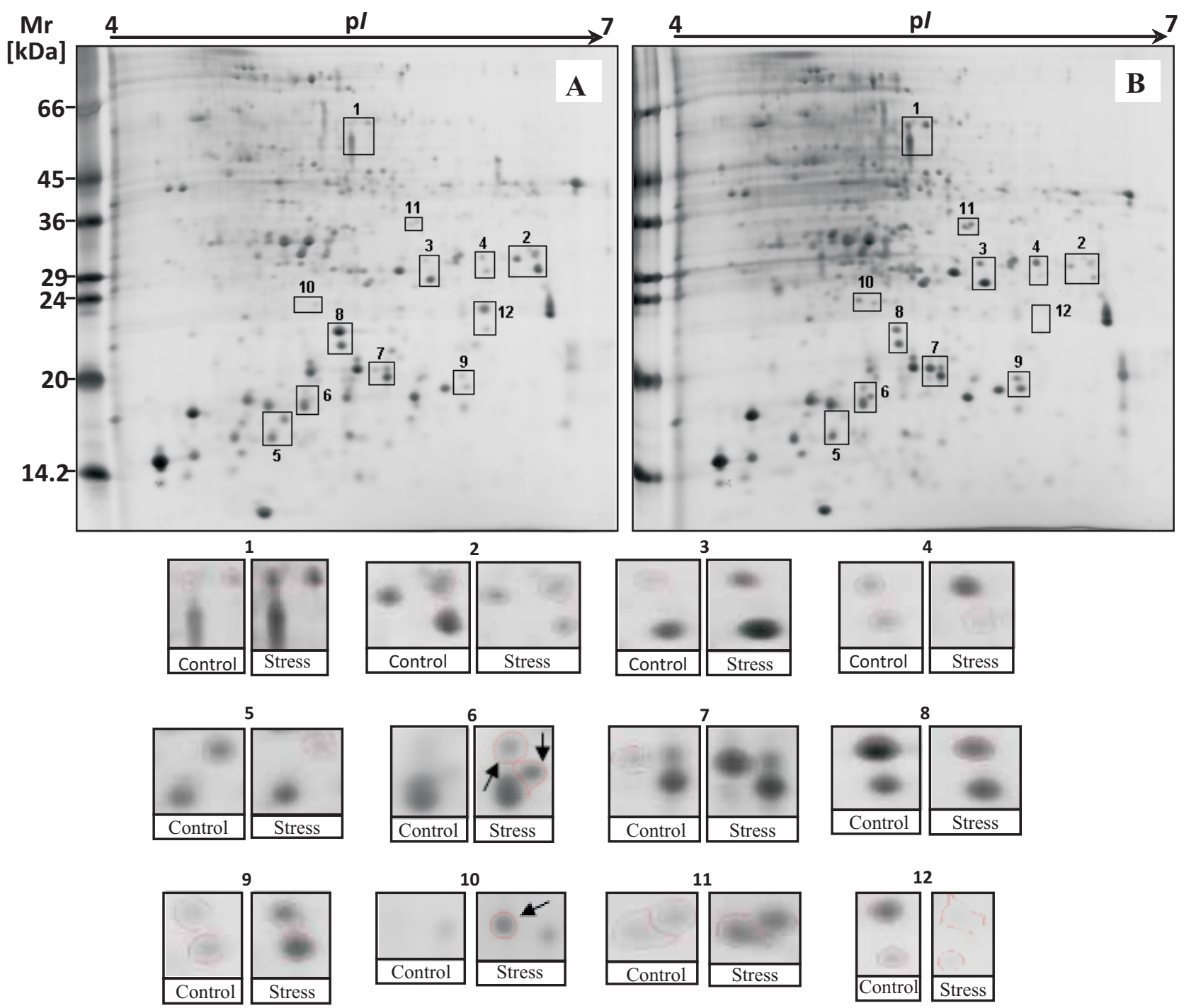

Figure 8. Comparisons of silver-stained 2D gels of proteins extracted from leaves of dwarf-cashew seedlings of clone CCP 06, grown under control (A) and salt stress $\left(17.4 \mathrm{dS} \mathrm{m}^{-1}\right)$ (B) conditions. Examples of proteins whose content were modified (increased or decreased) by salt stress more than two-fold are circled within panels 1-12. The arrows indicate proteins apparently synthesized de novo in response to salt stress.

compartmentalize the ions in the vacuole; as a consequence, leaf area and photosynthesis per unit leaf area decrease, thus further constraining shoot growth.

Although $\mathrm{K}^{+}$levels in many glycophytes are severely reduced under saline conditions, this effect was not observed here. As reported earlier for cowpea plants (Costa et al., 2003), leaf $\mathrm{K}^{+}$was higher than leaf $\mathrm{Na}^{+}$ concentration, even under saline conditions. In the cytosol, $\mathrm{K}^{+}$plays an important role in the activation of many enzymes, in protein synthesis and photosynthesis, and it mediates osmoregulation during cell expansion, stomatal movements and tropisms (Mäser et al., 2002). Therefore, it is possible that $\mathrm{Na}^{+}$exclusion from leaves combined with the capacity to maintain high concentrations of $\mathrm{K}^{+}$could be a tolerance mechanism for cashews at these salinity levels.

Several authors have shown that increased SOD activity may be related to $\mathrm{NaCl}$-induced oxidative stress tolerance (Dionísio-Sese and Tobita, 1998; Amor et al., 2005). However, SOD dismutates $\mathrm{O}_{2}{ }^{\bullet}-$ to $\mathrm{H}_{2} \mathrm{O}_{2}$, which is also a ROS. Thus, enhanced SOD activity should be accompanied by increases in the activity of $\mathrm{H}_{2} \mathrm{O}_{2}{ }^{-}$ 


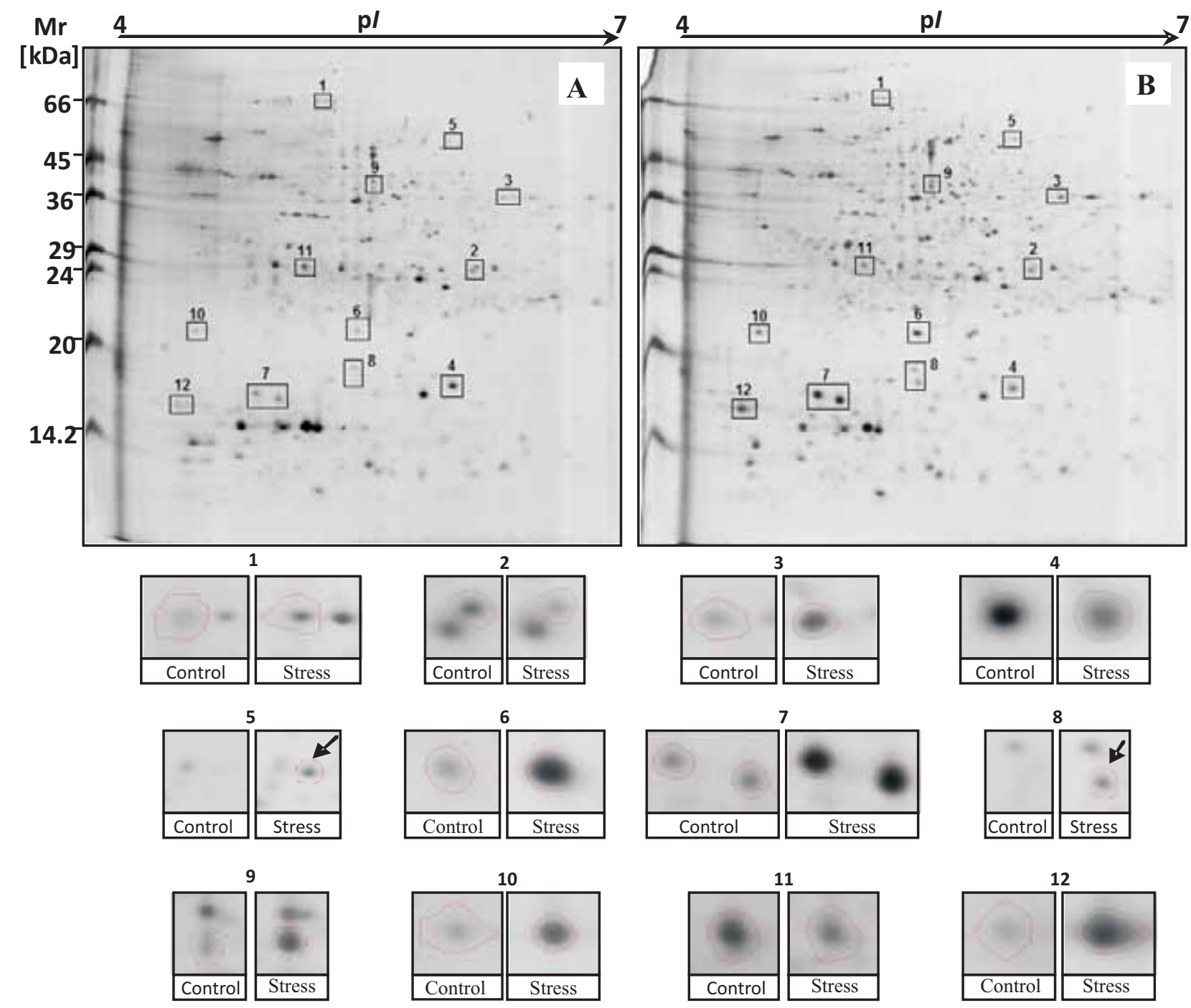

Figure 9. Comparisons of silver-stained 2D gels of proteins extracted from roots of dwarf-cashew seedlings of clone CCP 06, grown under control (A) and salt stress $\left(17.4 \mathrm{dS} \mathrm{m}^{-1}\right)$ (B) conditions. Examples of proteins whose content were modified (increased or decreased) by salt stress more than two-fold are circled within panels 1-12. The arrows indicate proteins apparently synthesized de novo in response to salt stress.

scavenging enzymes (Mittler, 2002). Overall, in our study, enhancement of activity of other antioxidative enzymes that may detoxify $\mathrm{H}_{2} \mathrm{O}_{2}$ (GPX and APX) was only found in roots. This suggests that the antioxidative defense system would not be as effective in leaves as it is in roots. Further support to this statement is provided by the larger MDA concentration (an indicator of oxidative damage; Møller et al., 2007) in leaves which accumulated more $\mathrm{Na}^{+}$and $\mathrm{Cl}^{-}$than roots. Moreover, since the cashew seedlings were grown under relatively low irradiance, increased MDA levels in leaves were unlikely to have resulted from increased rates of ROS production associated with photorespiration and the Mehler-peroxidase reaction. Therefore, our results lend some support to the statement of Cavalcanti et al. (2007), who also found distinct defense mechanisms against oxidative stress in leaves and roots of cowpea under salt stress.

Since seedlings were compared at the same developmental stage, the differences in the patterns of protein obtained for roots and leaves were not a response to the developmental stage per se. So, it would seem to be caused by increased salt concentration in the root medium. The simultaneous changes in protein expression and physiological responses suggest that changes in 
protein pattern play a critical role in these responses and may explain, at least partially, the differences among treatments. In addition to their possible role in osmoregulation of seedlings in response to unfavorable conditions, functioning as trans-membrane waterchannels or as enzymes involved in the synthesis of osmolytes (Salekdeh et al., 2002), some salt-induced proteins are expressed in order to minimize cell damage. These protective proteins include different classes of late embryogenesis abundant (LEA) proteins, which have molecular masses ranging from 10.0 to $30.0 \mathrm{kDa}$ and are thought to protect cells against dehydration (Hong-Bo et al., 2005). In this work, three proteins in the leaves with molecular masses of 18.8, 19.4 and $24.0 \mathrm{kDa}$ were apparently synthesized de novo, while the only proteins apparently synthesized de novo in the roots had a molecular mass of $17.3 \mathrm{kDa}$. On examining the molecular masses one might speculate that these proteins could be members of the LEA family, which accumulate in response to salt stress (Chourey et al., 2003).

We have shown that the deleterious effects of salt stress on seedling growth, as well as on oxidative stress, were more evident in shoots than roots, a fact possibly linked to a less robust antioxidant system in leaves, thus resulting in inefficient cell protection against ROS damage. Salt-induced changes in root and leaf protein patterns in cashew seedlings grown under low irradiance were also apparently related to direct effects of salt rather than resulting from a variant developmental stage. Thus, these changes in protein patterns may play a crucial role for salt stress acclimation in cashew seedlings.

Acknowledgements: We are grateful to the Conselho Nacional de Desenvolvimento Científico e Tecnológico (CNPq) and Fundação Cearense de Apoio ao Desenvolvimento Científico e Tecnológico (FUNCAP) for financial support.

\section{REFERENCES}

Amor NB, Hamed KB, Debez A, Grignon C, Abdelly C (2005) Physiological and antioxidant responses of the perennial halophyte Crithmum maritimum to salinity. Plant Sci. 168:889-899.

Ashraf M, Harris PJC (2004) Potential biochemical indicators of salinity tolerance in plants. Plant Sci. 166:3-16.

Ashraf M, Foolad MR (2007) Roles of Glycine betaine and proline in improving plant abiotic stress resistance.
Environ. Exp. Bot. 59:206-216.

Azevedo-Neto AD, Prisco JT, Enéas-Filho J, Lacerda CF, Silva JV, Costa PHA, Gomes-Filho E (2004) Effects of salt stress on plant growth, stomatal response and solute accumulation of different maize genotypes. Braz. J. Plant Physiol. 16:31-38.

Azevedo-Neto AD, Prisco JT, Enéas-Filho J, Abreu CEB, Gomes-Filho E (2006) Effect of salt stress on antioxidative enzymes and lipid peroxidation in leaves and roots of salt-tolerant and salt-sensitive maize genotypes. Environ. Exp. Bot. 56:87-94.

Bates LS, Waldren RP, Teare ID (1973) Rapid determination of free proline for water-stress studies. Plant Soil 39:205-207.

Beers Jr RF, Sizer IW (1952) A spectrophotometric method for measuring the breakdown of hydrogen peroxide by catalase. J. Biol. Chem. 195:133-140.

Blum H, Beier H, Gross HJ (1987) Improved silver staining of plant proteins, RNA and DNA in polyacrylamide gels. Electrophoresis 8:93-99.

Bohnert HJ, Nelson DE, Jensen RG (1995) Adaptations to environmental stresses. Plant Cell 7:1099-1111.

Boyer JS (1982) Plant productivity and environment. Science 218:443-448.

Bradford MM (1976) A rapid and sensitive method for the quantification of microgram quantities of protein utilizing the principle of protein-dye binding. Anal. Biochem. 72:246-254.

Cavalcanti FR, Lima JPMS, Ferreira-Silva SL, Viégas RA, Silveira JAG (2007) Roots and leaves display contrasting oxidative response during salt stress and recovery in cowpea. J. Plant Physiol. 164:591-600.

Cavalcanti Junior AT (1994) Morfo-fisiologia da germinação e estabelecimento da plântula do cajueiroanão-precoce (Anacardium occidentale L.). Lavras, Escola Superior de Agricultura de Lavras. PhD thesis.

Chourey K, Ramani S, Apte SK (2003) Accumulation of LEA proteins in salt $(\mathrm{NaCl})$ stressed young seedlings of rice (Oryza sativa L.) cultivar Bura Rata and their degradation during recovery from salinity stress. J. Plant Physiol. 160:1165-1174.

Costa PH, Silva JV, Bezerra MA, Enéas-Filho J, Prisco JT, Gomes-Filho E (2003) Crescimento em níveis de solutos orgânicos e inorgânicos em cultivares de Vigna unguiculata submetidos à salinidade. Rev. Bras. Bot. 26:289-297.

Dionísio-Sese ML, Tobita S (1998) Antioxidant responses 
of rice seedlings to salinity stress. Plant Sci. 135:1-9.

Dubois M, Gilles KA, Hamilton JK, Rebers PA, Smith F (1956) Colorimetric method for determination of sugars and related substances. Anal. Chem. 28:350-356.

FAO (2005) Global network on integrated soil management for sustainable use of salt-affected soils. http://www.fao.org/ag/AGL/agll/spush.

Gaines TP, Parker MB, Gascho GJ (1984) Automated determination of chlorides in soil and plant tissue by sodium nitrate. Agron. J. 76:371-374.

Giannopolitis CN, Ries SK (1977) Superoxide dismutases. I. Occurrence in higher plants. Plant Physiol. 59:309-314.

Heath RL, Packer L (1968) Photoperoxidation in isolated chloroplasts. I. Kinetics and stochiometry of fatty acid peroxidation. Arch. Biochem. Biophys. 125:189-198.

Hernández JA, Olmos E, Corpas FJ, Sevilla F, Del Río LA (1995) Salt-induced oxidative stress in chloroplasts of pea plants. Plant Sci. 105:151-167.

Hong-Bo S, Zong-Suo L, Ming-An S (2005) LEA proteins in higher plants: Structure, function, gene expression and regulation. Colloids Surf. B: Biointerfaces 42:107-113.

Kav NNV, Srivastava S, Goonewardene L, Blade SF (2004) Proteome-level changes in the roots of Pisum sativum in response to salinity. Ann. Appl. Biol. 145:217-230.

Lacerda CF, Oliveira HPM, Oliveira TS, Gomes-Filho E (2003a) Crescimento e acúmulo de íons em folhas de sorgo forrageiro submetido a soluções iso-osmóticas de sais $(\mathrm{NaCl}+\mathrm{KCl})$. Ciênc. Agron. 34:1-6.

Lacerda CF, Cambraia J, Oliva MA, Ruiz HA (2003b) Solute accumulation and distribution during shoot and leaf development in two sorghum genotypes under salt stress. Environ. Exp. Bot. 49:107-120.

Laemmli UK (1970) Cleavage of structural proteins during the assembly of the head of bacteriophage T4. Nature 227:680-685.

Malavolta E, Vitti GC, Oliveira SA (1989) Avaliação do Estado Nutricional das Plantas: Princípios e Aplicações. POTAFOS, Piracicaba.

Mäser P, Gierth M, Schroeder JI (2002) Molecular mechanisms of potassium and sodium uptake in plants. Plant Soil 247:43-54.

Mittler R (2002) Oxidative stress, antioxidants and stress tolerance. Trends Plant Sci. 7:405-410.

Mittova V, Tal M, Volokita M, Guy M (2002) Salt stress induces up-regulation of an efficient chloroplast antioxidant system in the salt-tolerant wild tomato species Lycopersicon pennellii but not in the cultivated species. Physiol. Plant. 115:393-400.

Møller IM, Jensen PE, Hansson A (2007) Oxidative modifications to cellular components in plants. Annu. Rev. Plant Biol. 58:459-481.

Munns R (2002) Comparative physiology of salt and water stress. Plant Cell Environ. 25:239-250.

Nakano Y, Asada K (1981) Hydrogen peroxide is scavenged by ascorbate-specific peroxidase in spinach chloroplasts. Plant Cell Physiol. 22:867-880.

Navarro A, Bañon S, Olmos E, Sánchez-Blanco MJ (2007) Effects of sodium chloride on water potential components, hydraulic conductivity, gas exchange and leaf ultrastructure of Arbutus unedo plants. Plant Sci. 172:473-480.

Parida AK, Das AB, Mittra B (2004) Effects of salt on growth, ion accumulation, photosynthesis and leaf anatomy of the mangrove, Bruguiera parviflora. Trees 18:167-174.

Rawat JS, Banerjee SP (1998) The influence of salinity on growth, biomass production and photosynthesis of Eucalyptus camaldulensis Dehnh. and Dalbergia sissoo Roxb. seedlings. Plant Soil 205:163-169.

Sairam RK, Tyagi A (2004) Physiology and molecular biology of salinity stress tolerance in plants. Curr. Sci. 86:407-421.

Salekdeh GH, Siopongco J, Wade LJ, Ghareyazie B, Bennett J (2002) A proteomic approach to analyzing drought- and salt-responsiveness in rice. Field Crops Res. 76:199-219.

Sousa MF, Campos FAP, Prisco JT, Enéas-Filho J, GomesFilho E (2003) Growth and protein pattern in cowpea seedlings subjected to salinity. Biol. Plant. 47:341-346.

Urbanek H, Kuzniak-Gebarowska E, Herka K (1991) Elicitation of defense responses in bean leaves by Botrytis cinerea polygalacturonase. Acta Physiol. Plant. 13:43-50.

Vaidyanathan H, Sivakumar P, Chakrabarty R, Thomas G (2003) Scavenging of reactive oxygen species in NaClstressed rice (Oryza sativa L.) - differential response in salt-tolerant and sensitive varieties. Plant Sci. 165:1411-1418.

Vinocur B, Altman A (2005) Recent advances in engineering plant tolerance to abiotic stress: achievements and limitations. Curr. Opin. Biotechnol. 16:123-132.

Yemm EW, Cocking EC (1955) The determination of amino-acids with ninhydrin. Analyst 80:209-213. 